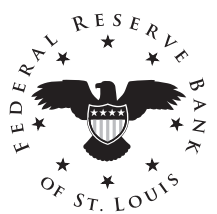

\title{
Unwinding the Current Account Deficit
}

\author{
Christopher J. Neely
}

$\mathrm{T}$

he U.S. trade deficit-the excess of imports over exportsclimbed to an all-time high of $\$ 61.04$ billion in February

2005. This merchandise trade deficit is, by far, the largest component of the current account deficit, which also records trade in services, payments on factors of production, and unilateral transfers. The U.S. current account deficit was a whopping 6 percent of GDP in 2004:Q4, the largest in U.S. history.

A capital account surplus is the necessary counterpart of a current account deficit. The capital account records transactions in real and financial assets, such as factories, stocks, and bonds. A country with a current account deficit and a capital account surplus-e.g., the United States-is selling claims on its future income in exchange for goods and services that it can consume or invest today.

A current account deficit can benefit a country by enabling it to consume or invest more than it otherwise could. Higher investment can generate faster growth. The drawback is that the deficit country must devote part of its future income to pay off the claims-(bonds, dividends).

The upper panel of the chart shows the components of the U.S. capital account surplus. Private purchases of U.S. assets have been important for many years but official (government) purchases have recently become much more important. The lower panel shows official purchases of U.S. assets by region. Asian central banks-China, Japan, South Korea, Taiwan, and India-have significantly increased their holdings of U.S. assets since 2001. Governments choose to hold highly liquid U.S. assets, such as Treasury securities, to defend their currencies' value and to insure against adverse economic conditions. The uncertainty associated with the war on terror might contribute to precautionary demand for safe U.S. assets. While there are several issues associated with these official purchases and the current account deficit, this cover page focuses on how the deficit will resolve.

Demand for U.S. dollar assets is not infinite; there are signs that foreign governments might already be diversifying their portfolios by reducing their purchases of U.S. assets. Some analysts claim that falling foreign demand for U.S. assets will devastate the U.S. economy through rapidly rising interest rates and a falling dollar, presumably coupled with severe recession.

A disaster scenario might be alarmist, however. While lower foreign demand for U.S. assets would very probably raise U.S. interest rates, weaken the dollar, and lower consumption and investment, such changes would not necessarily be accompanied by rising unemployment or falling output. A weaker dollar and higher interest rates would reduce U.S. consumption by making goods more expensive, but the dollar's depreciation would also make U.S. goods more competitive on world markets, which might increase U.S. exports, output, and employment. Adjustment will be necessary, but will not necessarily be disruptive.

In the long-term, domestic productivity will mainly determine the U.S. standard of living. And Americans' education, training, and willingness to save will determine domestic productivity. Our fate is in our own hands; not in those of foreign central bankers.

\section{Components of the U.S. Capital Account and Official Foreign Purchases of U.S. Assets, by Region}
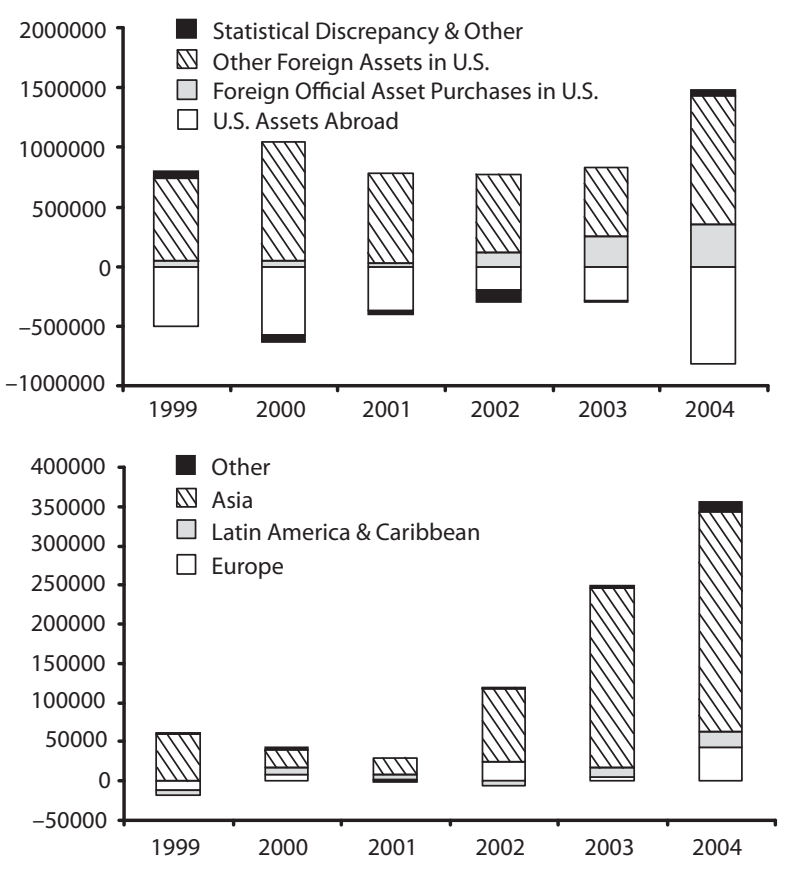

NOTE: The upper panel shows foreign purchases of U.S. assets and U.S. purchases of foreign assets. The lower panel breaks down official foreign purchases of U.S. assets - the light gray bars in the top panel—by region of purchase. 